\title{
第21回イ 見てある記
}

\author{
レポーター: 安食 弘二 \\ （株式会社リコー）
}

\section{はじめに}

今年も新春早々，第21回インターネプコンショー が 1 月22日から25日まで幕張メッセにて開催された。 会場は前年度より幕張メッセに移しているが，会場 の近郊はホテル等を含めイベント会場の拠点にふさ わしい環境が整ってきている。

毎年 6 月に行われている JPCA ショーと今回のイ ンターネプコンショーは, プリント回路板・実装技 術関係者にとっては欠かすことのできないイベント になっているといってもよい。また内容においても， この分野では世界最高のイベントといってもよいの ではないかと思う。よって海外からの出展者, 見学 者も数多く見受けられる。

\section{概 要}

イベントの内容は,

・インターネプコン・ジャパン'92（プリント回路 板・実装技術展)

・エレクトロテスト・ジャパン'92（エレクトロニ ク又試験・検査機器展)

・ ADEE・ジャパン'92（電子回路設計のための $\mathrm{CAD} / \mathrm{CAM}$ および関連機器展)

の3つに分かれて構成されているが「エレクトロニ クス設計・製造・実装・検査機器の専門展」といえ る。また, 特別講演を含め関連の専門技術セミナー が同時開催されている。

\section{講演・技術セミナー}

特別講演は「次世代のエレクトロニクス有望技術」，

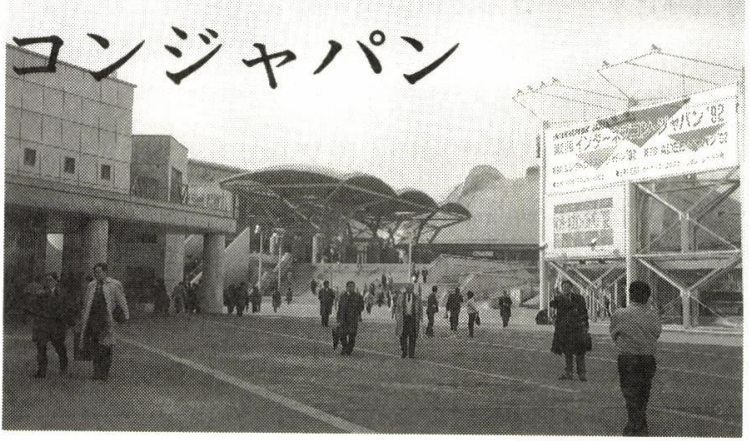

会場入ロより臨む

「グローバル化時代のエレクトロニクス」について 各数テーマずつであった。内容を約すと，「次世代有 望技術」については，商品化・製品化するまでには， 今回展示された技術がベースになり, 改良・改善が なされ実現化されていくと思うと, 今回はより一層 興味がわく展示見学であるとの主旨であった。「グロー バル化時代」については, 現在, 日本のエレクトロ ニクス産業が抱えている問題を的確にとらえていた ように思える。特に企業の海外展開・知的所有権問 題については, 現在, 企業が対面している事項とし てたいへん参考になった講演であった。

専門技術セミナーは，

・実装技術関連テーマ……26 26コース

・検査技術関連テーマ……6. 6 コース

・設計技術関連テーマ……6. 6 コース

とプリント回路関連技術の全体を網羅しており，参 加者にとってはたいへん有意義なセミナーになって いたと思われる。

\section{展示内容}

\section{1.インターネプコン・ジャパン'92}

今年も, より高密度化を目指す SMT 実装のための, 組立技術（装置・プロセス）・材料技術（フラック ス・はんだペースト）・部品技術（プリント配線板） を中心とした展示であった。

実装の自動装置は，大型高速化を狙った装置と小 型多機能を狙った実装機の二分化が明確になってき ている。特に高速化については，各社ステップアッ プした装置の展示が目についたが，次世代のパフォー マンスの高い装置になった感が強い。 
より高密度化を指向する中で，一つの目安である $0.3 \mathrm{~mm}$ ピッチのはんだ付けプロセス（信頼性を含む） に関する組立技術・製造技術は，完成度の高い技術 が確立してきたように思う。

プリント回路板における脱フロン化については, 今までも無洗浄化がいわれてはいたが，今回の展示 でプリント回路板の無洗浄化が明確に位置付けられ たように感じられた。中でも装置（ $\mathrm{N}_{2}$ リフコー, $\mathrm{N}_{2}$ フロー，フラクサー)，材料（フラックス，はんだペー スト）については見るべき技術が多くあったが，無 洗浄化を実施した時の問題として懸念される, 検査 時に広く使用されているフィクスチャー・ピンとプ リント配線板との接触について，フィクスチャー・ ピンの改善・改良がほとんど見られなかったのは残 念だった。

\section{2. エレクトロテスト・ジャパン'92}

$\mathrm{X}$ 線回折装置・画像解析装置・環境試験装置・実 装配線板外観検査装置等，信頼性面から解析・信頼 度確保ができる装置が多く見受けられた。高密度実 装が進む中で，今まではプリント回路板もはんだ付 け等，人による官能検査に多くを頼ってきたが，プ リント回路板のより高度な信頼度を確保するために は，ばらつきの少ない，微細検出が可能な装置によ る検查プロセスが，必要不可欠になってきている。 今回の展示に拈いても, この種の装置が数多く出展 されていた。

より進むであろう高密度プリント回路板の検査方 法について，今後どのような方向になるかについて は，各社とも試行錯誤の状態で明確な回答を得られ なかった。

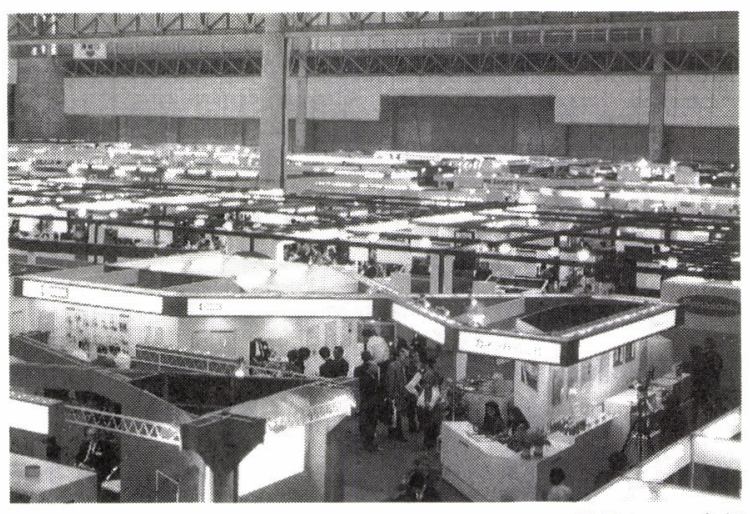

展示ホール内部

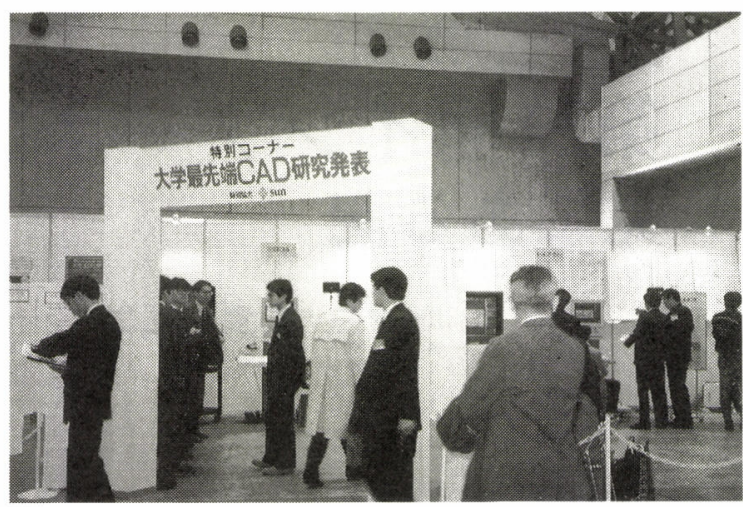

熱心な見学者でいっぱいの大学研究発表コーナー

\section{ADEE・ジャパン'92}

電子回路設計のための CAD / CAM を中とした 展示で,

・ LSI 設計支援ツール

・PCB 回路シミュレーション支援ツール

・PCBレイアウト設計支援ツール

が主な内容で，PCBレイアウトを主要としたCAD / CAM システムは, 回路シミュレーション・熱解析シ ミュレーション・電磁波解析シミュレーション等を 含めた，設計から組立まで一貫性をもたせたツール になってきている。

LSI 設計支援ツールは，今後広く展開していくであ ろうVHDL などの機能記述を用いた高位レベル設計 の支援ツールが数多く出展された。

その中で初めて大学におけるVLSI / CAD に関す る研究成果の展示が, 特別コーナーにて「大学最先 端 CAD 研究発表」の名称で出展された。大学の研究 活動を知る上でも，また今後の連携を緊密にする上 でも貴重な展示・発表であった。

\section{感 想}

今年も展示を見学しながら数多くの勉強をさせて もらった。今日ではこのインターネプコンショーは, 世界中のプリント回路板・実装技術関係者にとって 貴重なイベントになっているが，会場の展示を見る と, 日本人にしか理解できない所がほとんどで，グ ローバル化が叫ばれる中，もっと国際的な展示会で あって良いのではないかな？と思いながら見学を終 えたしだいである。 